\title{
Landslide Hazard Analysis by Using Arc GIS and Google Earth: A Case Study of Province 5, Nepal
}

\author{
Saurav Lamichhane* and Divya Bhattarai \\ Agriculture and Forestry University, Faculty of Forestry, Hetauda, Nepal
}

Submission: October 21, 2019; Published: November 20, 2019

*Corresponding author: Saurav Lamichhane, Agriculture and Forestry University, Faculty of Forestry, Hetauda, Nepal

\begin{abstract}
Province 5 of Nepal is one of the vulnerable province to natural and human induced disasters like landslides. This research was objectively carried out to estimate the number and area of the landslide and find out the district, municipality and rural municipality wise spatial distribution of landslides in the study area. The visible scars of landslides were digitized using Google earth Pro 7.3.3 and further analyzed in Arc GIS 10.3. Altogether, 701 landslides were found in 12 districts with total area coverage of 1940.17 ha. The largest area cover of landslide was found in Dang district with 326.99 ha and the lowest area cover of landslide of 8.63 ha was calculated in Rupandehi district. The highest occurrence 44 landslides occurred in Naubahini Rural Municipality of Pyuthan district followed by Sandhikharka municipality of Arghakhanchi district and Ghorahi sub-metropolitan city of Dang district with 43 and 42 landslides respectively. In Bardiya district, Bardia National park had 57 landslides instances on area of 260.62 ha. The highest area covered by landslides was 191.36 ha in Bijayanagar Rural Municipality of Kapilbastu district, 119.14 ha in Lamahi Municipality of Dang district, 106.66 ha in Sunwal Municipality of Nawalparasi district and 102.9 ha in Putha Uttarganga Rural Municipality of Rukum East district. Overall, this research depicts landslide area of whole province 5 and will be helpful to assist in further decision making. This type of the study can be very useful without much fieldwork and saves huge amount of time and money.
\end{abstract}

Keywords: Spatial distribution; Google Earth ${ }^{\mathrm{TM}}$; Arc GIS; Landslides

\section{Introduction}

Province 5 is one of the seven provinces established by the new constitution of Nepal. This province does not have an official database for landslides. Landslides, defined as the mass movement of rock, debris or earth down a slope [1], can be triggered by various external stimuli. Landslides are geologic hazards that occur on spatial and temporal scales in mountainous landscapes and are frequently responsible for considerable loss of life and property [2]. As one of the major natural hazards, landslides claim people's lives almost every year and cause huge property damage in mountainous areas $[3,4]$. The characteristics of various types of landslides are important to develop appropriate mitigation measures in the mountainous terrain of Nepal because the problems of landslides are different in different physiographic, geologic and climatic zones [5]. The inherently weak geological characteristics of rocks and soils have made the Himalaya fundamentally a very fragile mountain [5] and the triggering factors such as rainfall and earthquakes play their role to make the mountain very vulnerable to landslides and other mass wasting processes. The Midland areas have been highly susceptible to landslide due to complex interaction of natural and man-made factors [6]. Due to the rugged mountain topography, complex and fragile na ture of geological formation, high intensity rainfall in the monsoon season, Nepal is vulnerable to landslides [5].

A Geographic Information System (GIS) is a computer system that provides the ability to capture and analyze spatial and geographic data. Traditional remote sensing data are difficult to interpret and also need large a mount of time for further processing. With the introduction of Google Earth, visualizing the live data become easy and simple [8]. Google earth is used in diverse such as geology, public health, environment science, archaeological field to social and political issues like crisis management [9-12]. Google Earth is user friendly and free data source and many researchers also considered it as the democratization of GIS [8,13]. Google Earth is certifiably not an analytical tool hence it will not supplant GIS however it complements the GIS use, understanding this many GIS software developers are creating a slew of products that join its ease of use with their traditional analytic strengths [8]. If budget is a constraint in purchasing high resolution satellite imagery, then one could consider utilizing free Google earth images [14]. The landslide hazard mapping helps in timely mitigation and prevention of the risk factors associated with the landslides. Meanwhile, monitoring occurrence and condition of landslide 
in an extended geographical area requires significant amount of financial resource, human resource, and substantial amount of effort. Hence, remote sensing tools such as GIS can be used efficiently in determining and prioritizing the areas susceptible to the natural calamity such as landslide. Thus, this re- search was objectively carried out to estimate the number and area of the landslides and to find out the district, municipality and rural municipality wise spatial distribution of landslides in Province 5, Nepal.

\section{Materials and Methods}

\section{Study Area}

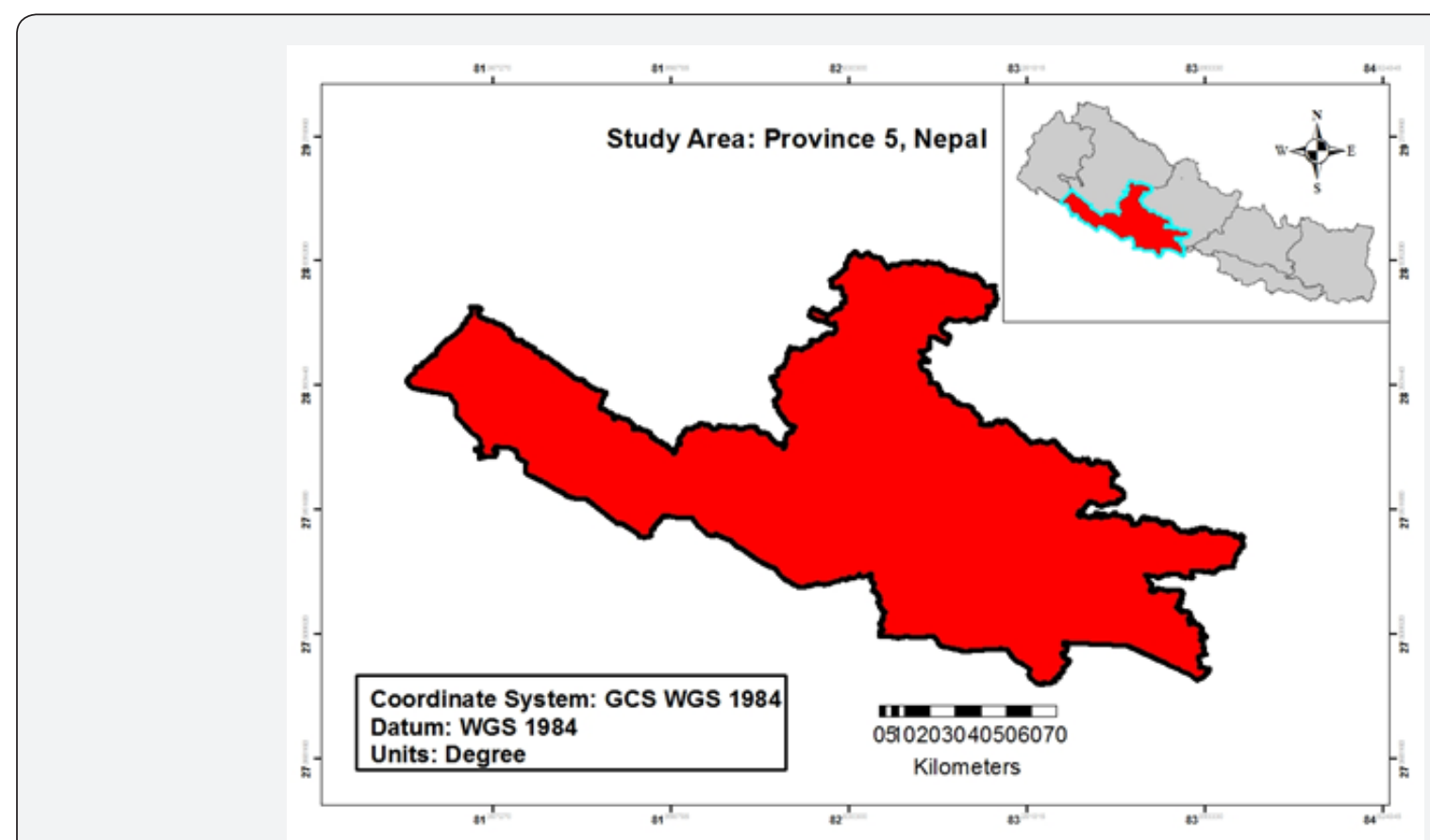

Figure 1: Study Area Map: Province 5, Nepal.

Province 5 is one of the seven provinces established by the new constitution of Nepal which was adopted on 20 September 2015. Butwal city has been declared the interim state capital of Province 5. In total, it covers an area of $22,288 \mathrm{~km}^{2}$ It borders Gandaki province and Karnali province to the north, Sudurpashchim province to the west, and Uttar Pradesh of India to the south. There are 12 districts, 4 sub-metropolitan cities, 32 municipalities, 73 rural municipalities and two national parks in the province. However, only those municipalities and rural municipalities were shown in the result section where landslide has been occurred (Figure 1).

\section{Methods}

\begin{tabular}{|c|c|c|}
\hline $\begin{array}{l}\text { Mapping Landslides } \\
\text { Polygon in Google } \\
\text { Earth Pro } 7.3 .3\end{array}$ & $\begin{array}{l}\text { Conversion of the } \\
\text { Data to KMZ } \\
\text { File }\end{array}$ & $\begin{array}{l}\text { Mapping, Analysis } \\
\text { and Interpretation, } \\
\text { In ArcGIS } 10.3\end{array}$ \\
\hline
\end{tabular}

Figure 2: Process of obtaining data from Google Earth and conversion into kmz file in Arc Gis.

This study is based on Remote Sensing data from Google Earth $^{\mathrm{TM}}$ and its interpretation in ArcGIS 10.3 software.

1. Based on the availability of Google earth imagery, landslides were mapped in the month of July and August of the year 2018 AD.
2. The polygons from the Google Earth were converted into kmz file so that it could be further processed and analyzed in ArcGIS 10.3 software.

3. The area, distribution and the numbers of landslides occasions were analyzed. (Figure 2). 
Results

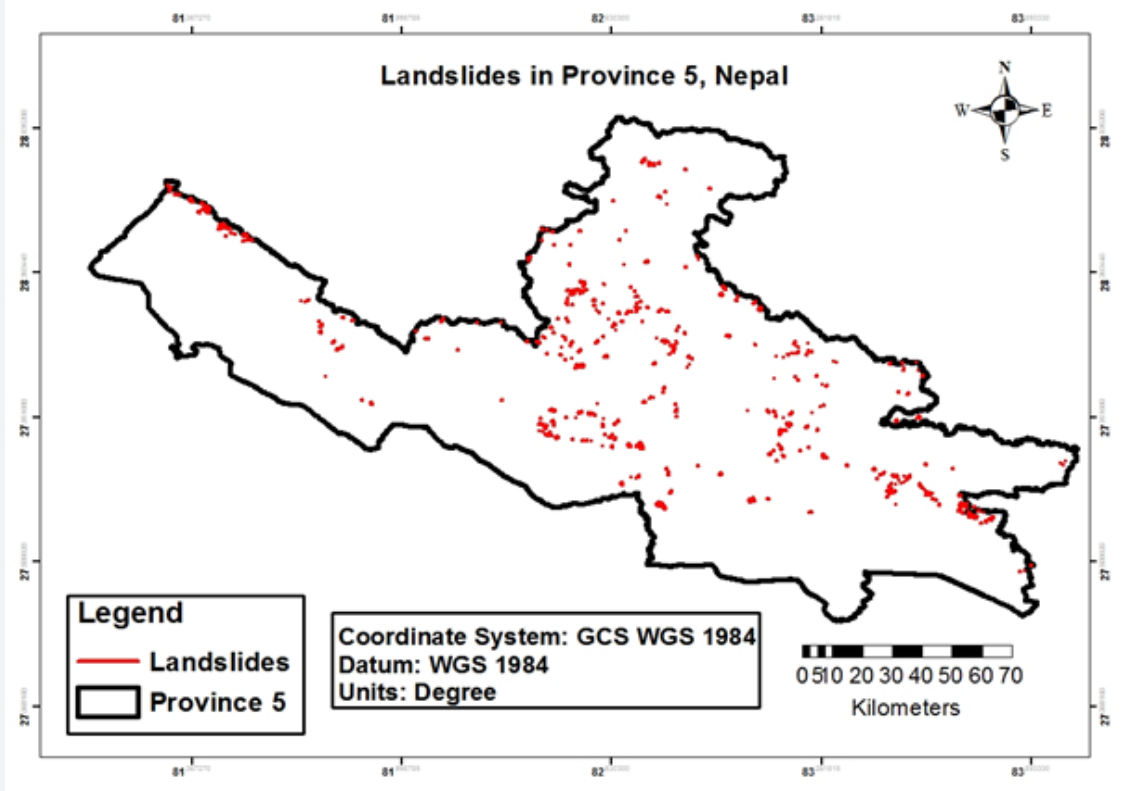

Figure 3: Spatial Distribution of Landslides in Province 5, Nepal.

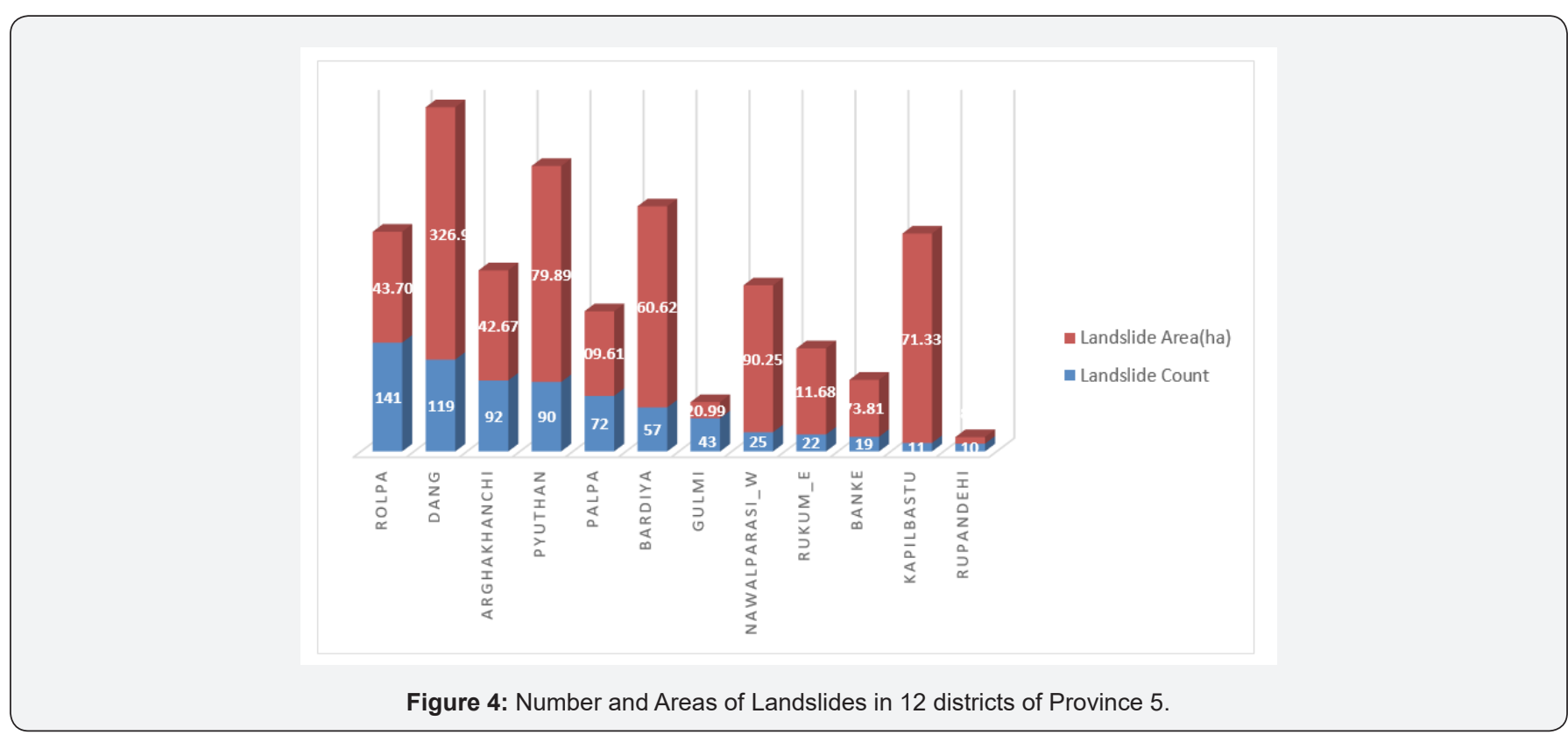

Table 1: Local Level Wise Landslide Number and Areas under 12 Districts of Province 5.

\begin{tabular}{|c|c|c|}
\hline District/Local Level & Number of Landslide & Area (ha) \\
\hline Arghakhanchi & 92 & 0.79 \\
\hline Bhumekasthan Municipality & 1 & 0.41 \\
\hline Chhatradev Rural Municipality & 2 & 1.08 \\
\hline Malarani Rural Municipality & 3 & 32.91 \\
\hline Panini Rural Municipality & 23 & 15.05 \\
\hline Sandhikharka Municipality & 43 & 92.43 \\
\hline Sitganga Municipality & 20 & \\
\hline
\end{tabular}




\section{Trends in Technical \& Scientific Research}

\begin{tabular}{|c|c|c|}
\hline Banke & 19 & 73.81 \\
\hline Baijanath Rural Municipality & 6 & 2.13 \\
\hline Kohalpur Municipality & 5 & 11.63 \\
\hline Rapti Sonari Rural Municipality & 8 & 60.05 \\
\hline Bardiya & 57 & 260.62 \\
\hline Bardiya National Park National Park & 57 & 260.62 \\
\hline Dang & 119 & 326.99 \\
\hline Babai Rural Municipality & 8 & 13.87 \\
\hline Banglachuli Rural Municipality & 9 & 7.8 \\
\hline Gadhawa Rural Municipality & 9 & 27.88 \\
\hline Ghorahi sub-metropolitan city & 42 & 77.62 \\
\hline Lamahi Municipality & 32 & 119.14 \\
\hline Rapti Rural Municipality & 14 & 70.55 \\
\hline Shantinagar Rural Municipality & 2 & 2.98 \\
\hline Tulsipur sub-metropolitan city & 3 & 7.15 \\
\hline Gulmi & 43 & 20.99 \\
\hline Chandrakot Rural Municipality & 1 & 2.76 \\
\hline Dhurkot Rural Municipality & 2 & 0.11 \\
\hline Gulmidarbar Rural Municipality & 2 & 0.28 \\
\hline Isma Rural Municipality & 19 & 3.37 \\
\hline Kaligandaki Rural Municipality & 7 & 3.46 \\
\hline Madane Rural Municipality & 2 & 0.17 \\
\hline Malika Rural Municipality & 3 & 0.52 \\
\hline Musikot Municipality & 2 & 0.22 \\
\hline Resunga Municipality & 3 & 2.77 \\
\hline Satyawati Rural Municipality & 2 & 7.33 \\
\hline Kapilbastu & 11 & 271.33 \\
\hline Banganga Municipality & 2 & 3.89 \\
\hline Bijayanagar Rural Municipality & 1 & 191.36 \\
\hline Buddhabhumi Municipality & 6 & 70.96 \\
\hline Shivaraj Municipality & 2 & 5.11 \\
\hline Nawalparasi_West & 25 & 190.25 \\
\hline Bardaghat Municipality & 3 & 81.92 \\
\hline Sunwal Municipality & 19 & 106.66 \\
\hline Susta Rural Municipality & 3 & 1.67 \\
\hline Palpa & 72 & 109.61 \\
\hline Mathagadhi Rural Municipality & 22 & 24.56 \\
\hline Nisdi Rural Municipality & 3 & 0.82 \\
\hline Rainadevi Chhahara Rural Municipality & 1 & 1.71 \\
\hline Rampur Municipality & 1 & 0.22 \\
\hline Ribdikot Rural Municipality & 1 & 17.88 \\
\hline Tansen Municipality & 1 & 9.27 \\
\hline Tinau Rural Municipality & 43 & 55.15 \\
\hline Pyuthan & 90 & 279.89 \\
\hline Gaumukhi Rural Municipality & 6 & 86.67 \\
\hline Mandavi Rural Municipality & 9 & 9.96 \\
\hline
\end{tabular}




\section{Trends in Technical \& Scientific Research}

\begin{tabular}{|c|c|c|}
\hline Naubahini Rural Municipality & 44 & 98.24 \\
\hline Pyuthan Municipality & 20 & 49.27 \\
\hline Sarumarani Rural Municipality & 9 & 1.5 \\
\hline Sworgadwari Municipality & 2 & 34.26 \\
\hline Rolpa & 141 & 143.7 \\
\hline Duikholi Rural Municipality & 3 & 2.35 \\
\hline Lungri Rural Municipality & 6 & 8.81 \\
\hline Madi Rural Municipality & 10 & 4.84 \\
\hline Rolpa Municipality & 33 & 19.95 \\
\hline Runtigadi Rural Municipality & 22 & 40.87 \\
\hline Sukidaha Rural Municipality & 12 & 4.4 \\
\hline Sunchhahari Rural Municipality & 4 & 25.99 \\
\hline Suwarnabati Rural Municipality & 25 & 11.56 \\
\hline Tribeni Rural Municipality & 26 & 24.94 \\
\hline Rukum East & 22 & 111.68 \\
\hline Bhume Rural Municipality & 4 & 0.45 \\
\hline Putha Uttarganga Rural Municipality & 15 & 102.9 \\
\hline Sisne Rural Municipality & 3 & 8.33 \\
\hline Rupandehi & 10 & 8.63 \\
\hline Butwal sub-metropolitan cities & 7 & 2.93 \\
\hline Devdaha Municipality & 2 & 4.35 \\
\hline Kanchan Rural Municipality & 1 & 1.35 \\
\hline Grand Total & 701 & 1940.17 \\
\hline
\end{tabular}

The map represents the landslides in Province 5 of Nepal. The red spots in the map show the landslide events. Most of the landslides were observed near to watershed areas. Altogether, 701 landslides occurred in 12 districts with total area coverage of $1940.17 \mathrm{ha}$. The largest area cover of landslide was found in Dang district 326.99ha and the lowest area cover of landslide was in Rupandehi 8.63ha. The district summary of landslides with number and area coverage is given in the figure below (Figures 3 \& 4) In Rolpa district 141 landslides occurred in area of 143.7ha, 119 landslides occurred in Dang district in area of 326.99ha and 92 landslides occurred in area of 142.67 ha in Argakhachi district. In Pyuthan district 90 landslides occurred in area of 279.89ha, 72 landslides occurred in Palpa district in area of 109.61ha, 57 landslides occurred in Bardiya National Park in area of 260.62 ha and 43 landslides occurred in Gulmi district in area of 20.99 ha. In Nawalparasi district 25 landslides occurred in area of 190.25ha, 22 landslides occurred in Rukum-East district in area of 111.68ha, 19 landslides occurred in Banke district in area of 73.81 ha, 11 landslides occurred in Kapilbastu district in area of 271.33ha and 10 landslides occurred in Rupandehi district in area of 8.63 ha. Similarly, the table below shows the number and area of landslide in local level under 12 districts (Table 1). In Arghakhachi district, the highest number of landslides was 43 in Sandhikharka Municipality and highest area of landslide was 92.43ha in Sitganga Municipality. In Banke district, highest of 8 landslides with total area cover of 60.05 ha occurred in Rapti Sonari Rural Municipality. In Bardiya National Park 57 landslides occurred in 260.62 hectares. In Dang district the highest number of landslides was 42 in Ghorahi sub-metropolitan city and highest area of landslide was 119.14ha in Lamahi Municipality. In Gulmi district, highest number of landslides was 19 of Isma Rural Municipality and the highest area covered by landslide was from Satyawati Rural Municipality i.e. 7.33ha. In Kapilbastu district, highest number of 6 landslide occurred in Buddabhumi Municipality and highest area covered by landslides was 191.36 ha in Bijaynagar Rural Municipality.

In Nawalparasi west district, highest 19 landslides with total area cover of 106.66 ha occurred in Sunwal Municipality. In Palpa district, highest landslide occcurence was 43 in Tinau Rural Municipality with total area cover of 55.15ha. In Pyuthan district, highest number of 43 landslides occurred in Naubahini Rural Municipality with total area cover of 98.24ha. In Rolpa district, highest number of land slides was 26 in Tribeni Rural Municipality and the highest area cover of landslide was 40.87 ha in Runtigadi Rural Municipality. In Rukum East district, highest number of 15 landslides occurred in Putha Uttarganga Rural Municipality with total area cover of $102.9 \mathrm{ha}$. In Rupandehi district, highest number of 2 landslides occurred in Devdaha Municipality with an area cover of 4.35 ha. 


\section{Discussion}

According to Nepal DesInventar report 2011, the most common type of disaster in the country is epidemic, followed by landslide and flooding. Since 1971-2010 AD, 2705 landslides are recorded with 4327 deaths and 1146 injuries [15]. According to Bhattarai et al. [16], a total of about 12,000 small- and large-scale landslides occur in Nepal every year, most of which often remain unnoticed and unreported mainly because of an inadequate information system, little economic impact, or little harm to humans and national infrastructure. The available data indicate that the annual rate of human deaths in landslides and related disaster events still stands at over 300 [17]. In Nepal, the number of landslide events peaks in the monsoon season, when they are triggered by high rainfall. Earlier Dixit [18] has prepared a landslide hazard map for Nepal which shows the mid hills were more susceptible to landslide. Between 1970 and 2018 in span of 48 years epidemics killed total 4,161 people in province number five; landslide alone killed 618 people, affected 66,512 families, 46 people went missing and 261 people were injured [19]. It is noteworthy that many small-scale disasters often go unreported. Among Mid-Hill and High Hill districts, Gulmi reported the greatest number of human causalities (142) followed by Pyuthan (132), Palpa (102) and Arghakhanchi (75) [19]. In terms of greatest number of families affected by landslides, Gulmi district has the highest number of deaths which is 19,713, followed by Arghakhanchi $(10,564)$, Rukum $(4,123)$, Palpa $(3,948)$, and Rolpa $(3,046)[19]$.

In our results, the number of landslides is high in districts Dang, Rolpa, Arghakhachi, Palpa and Pyuthan and according the area cover of landslide in all the ten districts excluding Banke and Rupandehi around 1 to 300 hectares is found under the effect of landslide. This result somehow matches with National Adaptation Programme of Action (NAPA) to climate change report 2010, prepared by Ministry of Environment. According to the report, Ropla and east Rukum categorised as high landslide risk districts with index (0.630-0.786); Dang, Gulmi, Pyuthan and Arghakhachi are categorised as medium landslide risk districts with index (0.47-0.629); Palpa is categorised as district with minimum landslide with index (0.001-0.46); whereas Parasi, Banke, Kapilbastu, Rupandehi and Bardia are the districts with very minimum landslide risk [20].

\section{Conclusion}

Since we lag in research regarding landslide, landslide mapping through Google earth and GIS would prove to be cost and time efficient. This data depicts landslide area of whole province 5 and assists in further decision making. Altogether, 701 landslides occurred in 12 districts with total area coverage of 1940.17 ha. Google Earth and GIS gives very important information on the spatial distribution of the landslide. It assists to set up priority areas for mitigation measures, helps in better understanding of the landslide as a hazard. Hence this type of the study can be very useful in disaster prone areas for decision making and planning without much of a fieldwork saving huge amount of time and money.

\section{Limitations}

Though the visuals were carefully observed, the lack of ground validation in this research and heavy reliance upon visual analysis only can subject this research to bias.

\section{Acknowledgement}

We would like to acknowledge Mr. Raj Kumar Rimal for his tremendous support during this research. We are also thankful to Dr. Ramasheshwor Mandal who paid a huge contribution in conducting this research and in report preparation.

\section{References}

1. Cruden DM (1991) A simple definition of a landslide. Bulletin International Association of Engineering Geology 43: 27-29.

2. McKean J, Roering J (2004) Objective landslide detection and surface morphology mapping using high-resolution airborne laser altimetry. Geomorphology 57(3-4): 331-351.

3. Hansen A (1984) Landslide hazard analysis. In: Brunsden D, Prior DB (editors.), Slope instability. Wiley, New York, pp. 523-602.

4. Chung CF, Fabbri AG (1995) Multivariate regression analysis for landslide hazard zonation. In: Carrara A, Guzzetti F (Editors.), Geographical Information Systems in assessing natural hazards, Dordrecht: Kluwer pp. 107-142.

5. Upreti BN (2001) Physiography and Geology of Nepal and their bearing on the landslide problem. In: Landslide hazard mitigation in the Hindu Kush-Himalayas, Tianchi L, Chalise SR, Upreti BN (eds.), ICIMOD publication, pp. 31-49.

6. Pradhan BK (2007) Disaster Preparedness for natural hazards: Current status in Nepal, ICIMOD, Kathmandu, Nepal, India.

7. Achyut L (2004) Practical action Nepal, Country strategy, Kathmandu, Nepal, India.

8. Butler D (2006) Virtual globes: The web-wide world. Nature 439(7078): 776-778.

9. Lisle RJ (2006) Google Earth: a new geological resource. Geology today 22(1): 29-32.

10. Parks L (2009) Digging into Google earth: An analysis of "crisis in Darfur". Geoforum 40(4): 535-545.

11. Patterson TC (2007) Google Earth as a (Not Just) Geography Education Tool. Journal of Geography 106(4): 145-152.

12. Sheppard SR, Cizek P (2009) The ethics of Google Earth: Crossing thresholds from spatial data to landscape visualisation. Journal of environmental management 90(6): 2102-2117.

13. Goodchild MF (2008) The use cases of digital earth. International Journal of Digital Earth 1(1): 31-42.

14. Malarvizhi K, Kumar S, Porchelvan P (2016) Use of High-Resolution Google Earth Satellite Imagery in Landuse Map Preparation for Urban Related Applications. Procedia Technology 24: 1835-1842.

15. (2011) DesInventar Nepal.

16. Bhattarai D, Tsunaki R, Mishra AN (2002) Water and Risk. In: Proceedings of Asia High Summit 6-10 May, ICIMOD, Nepal.

17. Shrestha HK, Bhandary NP, Yatabe R (2004) Trends in human life and 
economic losses from landslides and floods in Nepal. Proceedings of 2nd international seminar on disaster mitigation in Nepal, 8 November, Kathmandu pp. 103-110.

18. Dixit AM (1996) Disaster Management in Nepal, a Country Paper Prepare for UNCHS (HABITAT) and Presented to the Workshop Experiences in Disaster Management in Asia, November, Kalutara, Srilanka, India.
19. Gautam D, Mainaly J, Sapkota R, Regmi BR, Bhandari D, et al. (2019) Climate Change and disaster risk and vulnerability context of province number five. Oxford Policy Management, pp. 119.

20. MoE (2010) National Adaption Programme of Action (NAPA) to Climate Change. Kathmandu: Government of Nepal, Ministry of Environment (MoE).

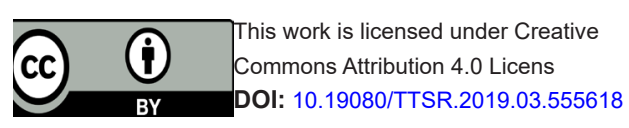

\section{Your next submission with Juniper Publishers will reach you the below assets}

- Quality Editorial service

- Swift Peer Review

- Reprints availability

- E-prints Service

- Manuscript Podcast for convenient understanding

- Global attainment for your research

- Manuscript accessibility in different formats

( Pdf, E-pub, Full Text, Audio)

- Unceasing customer service

Track the below URL for one-step submission https://juniperpublishers.com/online-submission.php 